\title{
'Can we name ourselves Savimbi?': Crevice Moments and Spaces of National Reimagination in the Angolan Scouts
}

\author{
JESS AUERBACH \\ Stellenbosch University \\ https://orcid.org/0000-0001-9064-1474
}

\begin{abstract}
This paper presents an analysis of contemporary citizenship in one group of Angolan boy scouts in 2014. It uses Shiera El-Malik's notion of 'crevice moments's to explore specific instances of dialogue and action which reveal opening and possibility within a largely closed state that have thus far not been reflected in existing scholarly literature. The paper further considers the reasons for scouting's popularity in post-war Angola, arguing that its military structure, religious basis, and focus on 'adventure' and social interactions have made it a highly desirable space for young people in a context where few opportunities exist for leisure activities. Finally, scouting enables a reconstitution of military and ideological symbols including uniforms, the socialist ideological construction of 'the new man,' and 'nature' in a way that, as one scout leader put it, is 'fit for peace'. In this process, past, present and future are reconstituted by a movement that itself is formed and transformed in contradiction and colonial echo.
\end{abstract}

\section{Introduction}

Benguela and Lobito are two of Angola's major cities, outside of its capital, Luanda. They are situated on the Atlantic coast, roughly halfway to the country's southern border. They link to each other via a 30 kilometer stretch of road that, during the country's long civil war (1975-2002) was at times almost impassable, but now takes only 20 minutes in a private car, or 40 in a candongueiro, the iconic blue and white Toyota Hiaces ubiquitous in so many of Africa's cities. ${ }^{2}$ In 2013 and 2014 I conducted doctoral fieldwork there, exploring the emergent Angolan middle class - its consumption, aesthetics and attitude, and the impact that this group was having on a gradually shifting social and political landscape ${ }^{3}$.

1 S. S. El-Malik, 'Intellectual Work "In-the-World": Women's Writing and Anti-colonial Thought in Africa', Irish Studies in International Affairs 24, 2013, 101-20.

2 A. M. Duarte, 'The Ambivalent Character of Reconstruction: Losers and Winners of the Lobito Transport Development Corridor, Journal of US-China Public Administration 10, 3, 2013, 1-13.

3 J. Auerbach, From Water to Wine: Becoming Middle Class in Angola (Toronto: University of Toronto Press, 2020). 
At the time of my fieldwork, Lobito and Benguela were sleepy cities from the perspective of many young people who had left formal schooling but not yet assumed the responsibilities of family life. Occasional music performances on the beach or in reconditioned outdoor cinemas and a few night clubs were all that existed to cater for the social and aesthetic needs of these Angolans. At the time there was no cinema, and only a few gyms. Restaurants and hotels were expensive, exclusive and out of reach of the majority who were nonetheless highly connected to global discourses through their cellphones. ${ }^{4}$

On Christmas night of 2013, I attended midnight mass with friends at the oldest Catholic church in Benguela. Scouts from the church 'troop' were active in both the religious ceremony itself and the organisation of both people and processes. I was struck by the seamless way the group of late adolescents operated together, helping to ensure the congregation was seated, leading singing, assisting in the officiation of the mass itself and taking care of younger children, many of whom were in cub or junior scout uniforms even at the late hour. I was also struck by what appeared to me as the incongruity of their uniforms - khaki shirts, cloth scarves carefully toggled in leather and long woolen socks in heavy boots in the midsummer heat.

Scouts played an important role in the social fabric of society in Lobito and Benguela. At the time they were the self-proclaimed 'largest youth organisation' outside of the dominant political party structures, ${ }^{5}$ and worked in partnership with several different Christian churches who typically hosted troops as part of the work of their congregations. A troop comprised both children and adults of both genders ${ }^{6}$ - 'packs' of cubs (aged 6-10 and by complete coincidence also called lobitos), 'groups' of junior and senior scouts (11-13 and 14-17 respectively) and 'clans' (clães, sing. clã) of caminheiros (18-25). They were run by volunteer 'guides' (guias), many of whom had been affiliated with the movement in childhood.

Troops gathered together by cohort, usually on the premises of their affiliate church itself, on Saturdays for curricula activities and on Sundays to support religious services. Often they met during the week as well, particularly the caminheiros, who included in their list of activities weekly Bible study. The local and national scout associations organised activities and excursions which frequently took members on overnight trips to different parts of the country. Scouting was important for the simple, but often underrated, reason that it was fun, and that it allowed people to expand their social networks beyond the confines of their immediate community. In this article I take seriously the 'fun' that was had by scouts, and the importance of this to a group of citizens who were of the first generation in the country's history to grow up in an independent, postcolonial country that was not at war.

J. Koebler, 'Angola's Wikipedia Pirates Are Exposing the Problems With Digital Colonialism.' Motherboard, 2016. http:// motherboard.vice.com/read/wikipedia-zero-facebook-free-basics-angola-pirates-zero-rating.

5 The JMPLA, Juventitude do Movimento Popular de Libertação de Angola, is the youth movement of the dominant political party.

6 Angola has not, at the time of writing, recognised the existence of non-binary gender categories. This is reflected in my choice of language and pronouns. 
Here, I use Shiera El-Malik's notion of 'crevice moments' to explore how the boundaries of Angolan citizenship were subtly contested and expanded through scout meetings. This reflected what Vasco Martins has termed the 'oscillating citizenship' of young Angolans in the contemporary moment, ${ }^{8}$ by which he means a form of citizenship in which individuals are 'nationals of the state' who may also be marginalised from its protections. Scout membership, I will argue, provides a space where such oscillations were visible. At times, membership in the organisation made scouts more legible to the Angolan state, and more 'included', especially if they had shown leadership abilities and loyalty within the organisation. At other moments, scouting enabled or made visible the limits of state belonging.

Outside of scouting, many members were structurally invisible, regardless of citizenship, and therefore had weak or nonexistent claims on resources or opportunities. This had the interesting effect of manifesting a rare space of dialogue and contestation within Angola, which contrary to claims made in much of the existing academic literature, enabled critique and reimagination of the Angolan state. The structures of these aspirations and experiences allow both a practical expansion of local opportunities through a powerful national network of friendships, and exposure to ways of thinking and being that successfully bridge Angola's militarised past and the more democratic future that many of today's young Angolans aspire to.

The article begins with an analysis of the social, political and economic context of the caminheiros of a troop that I refer to here as Troop \#21. It proceeds to a presentation of three key ethnographic incidents that I then analyse, following El-Malik, as moments where 'competing discourses [become] intelligible. The first, which I call Ruben's Choice, pertains to a scout leader's decision to prevent a subsection of his clã from naming themselves after the former UNITA ${ }^{9}$ leader, Jonas Savimbi. The second, Bruno's Compromise, examines a decision taken by a popular scout leader to leave the organisation and commit his time full-heartedly to the MPLA instead. The third 'crevice moment', Hipólito's Sacrifice, considers the reaction to the tragic death of another young scout leader within the scout community itself, and how this death was reconfigured as an example of moral excellence and maturity that could be of benefit to the entire nation.

From these 'crevices', I will argue, emerges a new interpretation of post-war citizenship that expanded the possibilities open to young Angolans in Lobito-Benguela. In the conclusion, I suggest that the 'mafia for good', which the scouts aspire to create, is an interesting example of a new citizen formation that is grounded in both local and translocal aspiration, experience and belonging.

V. Martins, 'Politics of Power and Hierarchies of Citizenship in Angola', Citizenship Studies 21, 1, 2017, 100-115. https://doi.org/ $10.1080 / 13621025.2016 .1252718$.

9 União Nacional de Independência Total de Angola, or National Union for the Total Independence of Angola. This party was at war with the now-dominant MPLA for most of the late $20^{\text {th }}$ century, a war which ended only with the death of the party's leader, Jonas Savimbi, in 2002. 


\section{Troop \#21}

Troop \#21 were affiliated with the Catholic Church in Catumbela. Located on the road between Lobito and Benguela, Catumbela is a small town nestled at the mouth of one of the rivers that used to bring slaves to the coast before their journeys to the Americas. ${ }^{10}$ In 2014, dilapidated colonial-era houses lined a few main roads in the center of town, and many of the population were very poor, in both national and international terms. ${ }^{11}$ Most lived in the surrounding hills in two room concrete block houses, which had only very recently been electrified and in many cases did not have running water. Many were teachers, including someone who I call here Ana-Flora. ${ }^{12}$

Ana-Flora was a government school history teacher as a primary job, but supplemented her income with extra classes at the private school where I taught music. She was also an avid and very proud scout leader. After several discussions about the movement over our lunch breaks, she invited me to join her troop at their weekly Saturday morning meetings and on some of their excursions. The troop's membership were mostly children from the local community who had at least one working parent, but whose household income was relatively low. Nobody owned a car, a few had motorcycles, and all of them were enrolled in public, not private schools, which was an informal indicator of financial liquidity in the area.

The schooling system in Angola, like in so many other places, is overstretched and under resourced, though continuous efforts are being made to improve it. ${ }^{13}$ AnaFlora had grown up in Catumbela and was well aware of the many social challenges the area faced. She felt that her work in the schooling system was constrained however and had been drawn to the scout movement because of its emphasis on both holistic education and community intervention. She herself had opted to become a scout leader for the senior scouts (late adolescents and the same age as her school students) but introduced me to Chefe (literally 'chief', a term of respect for scout leaders) Pedro, who was responsible for the caminheiros.

The caminheiros were all 18 to 25 , and almost all of them had been active in scouting before. Importantly, they were known by the church community to be 'good' people, who lived what were deemed moral lives according to church elders and active members, and who fulfilled their social roles without compromise. All caminheiros were confirmed via a public 'Promise' ceremony in the church itself and opportunity was given both formally and informally for members of the congregation to approve (or disapprove) participation.

10 J. Thornton, A Cultural History of the Atlantic World, 1250-1820 (Cambridge: Cambridge University Press, 2012); M. P. Candido, An African Slaving Port and the Atlantic World: Benguela and Its Hinterland (Cambridge: Cambridge University Press, 2015).

11 C. M. Lopes, 'A Economia Informal Em Angola: Breve Panorâmica', Revista Angolana de Sociologia 4, 2014.

2 All names are pseudonyms.

13 F. Coxi, L. Desastre and C. J. Y. G. Román, 'La Evaluación de La Reforma Educativa En La República de Angola', Pedagogía Profesional, 15, 4, 2017. 
Extensive scholarship exists on the role of the church in Angola. ${ }^{14}$ This literature points to the significance of the church as a social force in the development of Angolan nationalism and the role that is has played in creating and maintaining structures of education, information and control. Both Catholic and Evangelical entities have been integral to the emergence of Angolan institutions, and in shaping the thinking of many of its contemporary leaders. Churches had opened education to all Angolans, and it was in the church schools that scouting in Angola originally took off. Scouting is by no means the only youth organisation that exists via church structures, but it is striking, at least in part, because it so directly connects to the global scouting movement that is both religious and secular.

One of Ana-Flora's mentees was a young woman named Gabriella, who had recently turned 18 and had 'graduated' from senior scouts into the caminheiros. At the time of my fieldwork she was preparing to make her Caminheiro Promise, which entailed publicly committing to live by both the laws of scouting and of the Catholic Church, which were understood to be mutually-reinforcing institutions. When I asked her why she had joined the scouts, she explained as follows:

I like the scouts because they are unified. I am from Lobito and I was raised by my mom and my adopted father. I have three siblings, all younger than me, and I was sent to Luanda to clean the house of a lady, so that with the money I could keep going to school. But then my stepfather died and I came back to help my mother. While I was in Luanda I looked for my biological dad but he never acknowledged I existed. I found out who he was and his address, and I went to see him. He was so cruel; he shouted at me in the street and said he never wanted to see me again. It was very hard. A man was watching from the side of the road. He called me afterwards and he said 'filha [daughter], everybody has troubles. Even rich people who have cars you don't know what is in their hearts. It turned out he was a scout Chefe, and he invited me to join his troop there in Luanda. He raised money for me to buy the scout scarf [considered the most essential element of the uniform] and to make the Senior Scout Promise. And even though I am here now, he is like a father to me, and I speak to him almost every day.

Gabriella was in many ways representative of the young women and men who formed part of Troop \#21. Growing up, her home life had been complex and she did not have much money. In scouting, she had found community, friendship, generosity and consistency, and indeed her fees were still paid through collections and donations via the Church, as well as the individual Chefe in Luanda, who provided her with her uniform. She describes the importance of 'unity' to her life, and the security

14 c.f. Thornton, 1984; D. Birmingham, 'Merchants and Missionaries in Angola', Lusotopie, 1998, 345-55; Birmingham, 1998 ; D. Péclard, 'Religion and Politics in Angola: The Church, the Colonial State and the Emergence of Angolan Nationalism 1940-1961', Journal of Religion in Africa, 28, 2, 1998, 197-293; R. L. Blanes and A. Paxe, 'Atheist Political Cultures in Independent Angola', Social Analysis 59, 2, 2015, 62-80; R. L. Blanes, Prophetic Trajectory: Ideologies of Place, Time and Belonging in an Angolan Religious Movement (New York: Berghan Book, 2014). 
that came from identifying with the movement. That a stranger would respond to her with such kindness, she also told me, had been a core part of what had initially attracted her to scouting, and was a lesson she carried with her. Ana-Flora was another example of an individual who treated all young people she came across as potential students and also as potential scouts. To this end, she demanded a high standard of not only intellectual work, but also moral and civic behaviour.

Due in part to the efforts of individuals such as Chefe Ana-Flora, the stereotype of a scout being the one to help old ladies cross the road was as true in Angola as it might be elsewhere ${ }^{15}$, but there was more to the movement than that. In an interview with one of the movement's most senior leadership, the perceived long-term benefits of scouting were made very explicit:

You know scouting is something very helpful for a young person to put on their CV! Many join the military, the police force, many teach, many work in banks. You know scouting could be seen as an organisation that is almost mal-feito [badly made] but mal-feito for good. Scouting is like a little mafia you see, of people who help each other. Scouting is a mafia for good [his emphasis].

The term 'mafia for good' was one I heard frequently to describe scouting. The Chefe quoted above made an interesting choice when he used the term mal-feito to describe the organisation he led. It showed awareness of the critical importance of networks in Angola - an importance that usually far surpassed, for example, details such as merit or competence. It was both mal-feito and it was a 'mafia', in part because of the way it created and maintained its network (in a sense, an open acknowledgement of corruption). Yet it was a 'mafia for good' which aimed, explicitly, to help others and to manifest the values and commitments of Lord Robert Baden-Powell, the $19^{\text {th }}$ century Englishman who was the movement's founder. ${ }^{16}$

This tension allowed scouting to be both permissible to the Angolan state, and to enable some dialogue towards the values described by Baden-Powell. ${ }^{17}$ It was an example of what Paul Robson and Sandra Roque call a 'mechanism of mutual support, solidarity and collective action'18 that existed in a space where MPLA political membership had become the primary way to access resources and power and, significantly, many people within it had ambitions to rise through the ranks of not only scouting, but also politics. Many authors have rightly argued that the space for discursive dialogue in Angola is very small. ${ }^{19}$ This paper shows, however, the

15 T. Parsons, Race, Resistance, and the Boy Scout Movement in British Colonial Africa (Athens: Ohio University Press, 2004).

16 A. B. F. Leandro and R. C. G. Nascimento, 'Escotismo, Educação e Civismo : A Propagação Dos Ideais de Baden-Powell Em Campina Grande-PB: Scouting, Education and Civility : The Spread of Ideal Baden-Powell in Campina Grande-PBl', Revista Humanidades, 30, 2, 2015, 333-46.

17 R. Baden-Powell, Scouting for Boys (London: Dover Book, 1908).

18 P. Robson and S. Roque, "'Here in the City There is Nothing Left over for Lending a Hand": in Search of Solidarity and Collective Action in Peri-urban Areas of Angola', Guelph: Development Workshop 2001.

19 R. S. de Oliveira, Magnificent and Beggar Land: Angola Since the Civil War (London: Hurst, 2015); J. Schubert, Working the System: A Political Ethnography of the New Angola (Ithaca: Cornell University Press, 2017); M. Moorman, Powerful Frequencies: Radio, State Power, and the Cold War in Angola, 1931-2002 (Cleveland: Ohio University Press, 2019). 
significance of easily overlooked organisations such as the scouts which do not call for revolution but nonetheless chip away at the internalised boundaries of thought and expression. I explore this process through an analysis of three 'crevice moments' that showed the delicate dance of a 'mafia for good' in action.

\section{First crevice: Ruben's choice}

In the Angola of 2014 the importance, power and influence of the ruling MPLA was almost palpable. Its leader, José Eduardo dos Santos, had been widely proclaimed the 'architect of peace', a frequently heard phrase used to describe his leadership through the end of the civil war and into the period of national reconstruction and redevelopment. ${ }^{20}$ Loyalty to the MPLA, and with it Eduardo dos Santos, was expected as an everyday action. ${ }^{21}$ The opposition, UNITA, was much diminished since its transformation from 'rebel' army to political party following the end of the civil war, though Lobito-Benguela had historically been a place where there was much support for it.

UNITA's presence was still felt, of course, both in private conversations and even at events such as Independence Day celebrations, where a small UNITA contingent would be noisily and enthusiastically present, even if largely drowned out by the supporters of the MPLA. Many individuals would admit in private to have been members of UNITA at other times, but nonetheless thought it prudent to carry MPLA membership cards, often visibly, and to pronounce their loyalty to the MPLA loudly and publicly. In addition, CASA-CE, ${ }^{22}$ a break off party from UNITA, was increasingly making inroads in both the area and the country, and indeed would do almost as well as UNITA in the 2017 elections. In addition, a small group of young people known locally as the revus had begun openly protesting José Eduardo Dos Santos' reign from about 2011 onwards. ${ }^{23}$ Though certainly not widely accepted, it meant that against the backdrop of the longue durée of Angola's political history, there was a gradual opening to the contestation of the state, albeit one that at times 'cracked down' in very violent ways. There was a widening of the kinds of discourses and perspectives that might be voiced in the public realm, even at risk of warning and sometimes social or political sanction.

Amidst this increasingly complex political terrain, the scouts presented an interesting space for dialogue. On one hand, especially amongst the senior scouts and caminheiros, the movement created a space for young people from around the country to meet and exchange ideas. Many, if not most, had been exposed to the revus and to some of the materials that they circulated, ${ }^{24}$ to the widening spaces of social media and to the lyrics of Angola's popular music scene which has a long history of political

20 G. J.S. Lázaro, 'Angola: Discursos e Práticas Dominantes de Reconciliação e Construção Da Nação', Instituto Universiteario de Lisboa, 2010.

21 de Oliveira, 2015.

22 Convergência Ampla de Salvação de Angola - Coligação Eleitoral, The Broad Convergence for the Salvation of Angola - Electoral Coalition.

23 J. Pearce, D. Péclard and R. S. De Oliveira, 'Angola’s Elections and the Politics of Presidential Succession', African Affairs 117, 466, 2018, 146-60. https://doi.org/10.1093/afraf/adx045.

24 c.f. CentralAngola7311, 2011. 
engagement and critique. ${ }^{25}$ At the same time, many members of the Angolan scouts were also active in MPLA structures, and to a certain extent the movement, like everything else, required a working relationship with the MPLA in order to function. That tension became palpable in a meeting of the caminheiros officiated by a young (25 year old) chefe named Ruben.

Ruben lived on his own in a one room cement block house, into which he had just installed air-conditioning. He taught in a primary school by day, supported both parents financially, and studied towards a university degree by night. His weekends were filled with the activities of scouting - organisation, the facilitation of group meetings, individual support to members of his troop when needed and occasionally leadership trainings with either the Catholic church or the scouting executive. Ultimately, scouting crept into all aspects of his work, as he was well aware that at university he tended to study with other scouts, and that with his family he tried to manifest the values and principles that he absorbed from the movement and pass them on through example to his younger siblings.

As stated, each troop of scouts is divided according to age cohorts, with caminheiros being the eldest and subgroups by age cohort within each troop. The following dialogue took place during a meeting of the caminheiros in which new clães were being formalised, presided over by Chefe Ruben.

Chefe Ruben: Servir! [to serve - the way scouts greet one another] Group: Servir!

Chefe Ruben: We need to choose a name for our clã. It needs to be a name that is inspiring; it should be after a great person in history.

Gabriella: If that is the criteria, how come there are no clães called Savimbi?

Savimbi was a leader and he was inspiring.

The room went silent both at the mention of Jonas Savimbi's name and the statement that he had inspired. Jonas Savimbi was both the founder and former military leader of UNITA, whose death ended the civil war. He was rarely acknowledged and still more rarely even subtly praised, as to do so was seen to provoke the ruling MPLA government by actively reminding the population that there had once been a very real alternative to the current status quo, an alternative, in fact, perceived by some as being worth going to war for. ${ }^{26}$ Pausing for a moment, Ruben finally responded:

To name a clã Savimbi would be against common sense! We all know that Savimbi was not an example for us to follow. It would be impossible to give that name, because we have to go with the values of our society, and the majority say that that is not okay.

M. Moorman, Intonations: A Social History of Music and Nation in Luanda, Angola, from 1945 to Recent Times. (Athens: Ohio University Press, 2004); M. Moorman, 'Anatomy of Kuduro: Articulating the Angolan Body Politic after the War', African Studies Review 57, 3, 2014, 21-40.

26 Pearce, Péclard, and de Oliveira 2018; J. Pearce, Political Identity and Conflict in Central Angola (Cambridge: Cambridge University Press, 2015). 
'What is the majority?' somebody else asked, and the conversation quickly became heated. Ruben, however, would have none of it, and called for order repeatedly. He put a stop to the discussion and instead insisted that the group undertake a dictation of Angolan Scout Law, which the caminheiros painstakingly transcribed into the notebooks they all had with them, and were instructed to memorise and be ready to be tested on by the following week. Though the discussion ended for the moment, it was picked up by many in the group as they left the meeting and susurrated throughout the months that followed. For some in the troop, any action that might be read as inciting to the state was to be avoided at all costs, illustrating an argument put forward by Christine Messiant who suggested that part of the MPLA's political strategy was to create a context in which critiquing the MPLA was understood to be critiquing the nation itself, ${ }^{27}$ with the nation being sacrosanct ${ }^{28}$.

Many individuals and families had a history of persecution in the face of national criticism. Yet others, perhaps emboldened by the acts of the revus, considered it important to at the very least ask questions, such that, again quoting El-Malik 'competing discourses [become] intelligible. ${ }^{29}$ In a later conversation, Ruben spoke very differently to me about Savimbi:

Savimbi never killed people you know. It was his soldiers who killed. But we can't say that because in Angola freedom of speech is not really allowed. It's complicated here. I myself am not like other Angolans, because I think about it, you know, how strange it is we cannot speak. ... I also refuse MPLA membership, because it's important to be neutral, and then to create space for opposition. My dad was in the MPLA, a military man, and I know it was not all good. I have this memory of growing up in the war, I was six, maybe seven years old. I grew up in [the interior city of] Huambo, where the war was bad. There was a day where my dad's friend was shot in front of us, I don't know why. Not once but ten or eleven times, they just wouldn't stop. Sometimes I wake up dreaming of it. People here in Benguela province have no idea about how the war really was, even though they pretend they do. It was so hard. I was a chubby kid you know, just naturally chubby like some children are, and I was so hungry in that time. I also remember how the UN would come and they would measure children's wrists and only give food to the thin ones. I carry that memory too. I was too fat, but so hungry. That was the war.

In both his reflections and his action when facilitating a discussion, Ruben showed an awareness of the complexity of freedom of speech in what was - and arguably still is - effectively a one-party state in which the possibilities for imagining any 
alternative reality have been largely foreclosed. ${ }^{30}$ In the role of leader of the group, he felt it was his duty to ensure nothing was said that might have negative consequences for either individuals or for the collective - in this case the scouts. His understanding of the issue at hand was nuanced, however, and included not only an awareness of the complexities of history, but a skill ${ }^{31}$ in the management of discourse and risk.

Ruben knew that the 'opening' of Angolan society was not yet at a point where such an explicit political challenge would be accepted, even if at a personal level, he found reason to respect Jonas Savimbi himself. As such, he chose to shut down the public discussion, though by no means that which took place in private. A second example of such decision making can be seen in the figure of Chefe Bruno, described below, who made what he called once 'a deal with the d....' for the sake of his extended family.

\section{Second crevice: Bruno's compromise}

Bruno came from an extremely poor family in the outskirts of Lobito, which had no political connections. As a child he had become entranced by young people whom he saw wearing the scout uniform - the uniform appealed to his orderly sense of fashion and reminded him of photographs of an unmet grandfather in military fatigues that his mother treasured. He persuaded his parents to let him join a group of cubs in the early 2000s where he formed friendships that remained the core source of his social support in 2014. Bruno worked his way through the ranks, and his dedication to scouting quickly became a well-known aspect of his character. Bruno was the loudest singer, the fastest runner and the quickest to recite the laws of scouting. He was a deeply observant Catholic who did not smoke, rarely drank and infected everyone around him with the sincerity of his enthusiasm, whether it be to God, to scouting or to the task at hand.

Bruno took on as many leadership roles as he could, particularly in scouting. The skills and contacts that he gained through the network enabled him to connect with several NGOs and the local Junior MPLA branch. He earned much needed funds for the family by interpreting for the NGOs, as he was also gifted with language and able to move fluidly between Kimbundu, Ovimbundu, Portuguese, English and Spanish. Kimbundu, Ovimbundu and Portuguese were languages used by his extended family, and English he learned in school with a committed teacher. He picked up Spanish through frequent interactions with the Cuban faculty at the local university.

Being kind, sincere, intelligent and boundlessly enthusiastic, Bruno became, in adolescence, one of the best-known young people in Benguela-Lobito, and by the time I met him, an influential youth leader whose presence and networks spanned several organisations. Scouting, however, as he told anyone who would listen, was his first love. At the time when Bruno and I came to know each other, his family had just made a difficult decision: he was to take an official role within the MPLA political

30 E. Morier-Genoud, Sure Road? Nationalisms in Angola, Guinea-Bissau and Mozambique (London: Brill, 2012).

31 T. Ingold, The Perception of the Environment: Essays in Livelihood, Dwelling and Skill (London: Routledge, 2000). 
structure. The decision was difficult because Bruno knew that it would compromise his ability to be critical of 'the Party' (he had friends who were revus, though he was discreet in his meetings with them) and to some extent would limit his scouting activities due to radically decreased available time and the necessity of representing the MPLA at any event with a public audience.

Bruno also knew that many people who looked up to him and were quietly very critical of the State, would see him as selling out. 'But that's exactly what I am doing, you see,' he explained,

I have no choice. The MPLA said I am getting too influential, and now I must either be with them, or they will say I am against them, and cut my water and my light. I called all the elders in my family together and asked them what I should do, and they said, my son, you are a poor boy with nothing - you must join the party, it is the only way, or they will put you in jail. They said to me 'Bruno, it is not about ideals, but this is just how it is in Angola. And so, I have done it, I am with the party, and I no longer go to talk to the NGOs, though the people in them know that in my heart I am still there with them.

The phrase that Bruno used, to 'cut water and light' was a common one at the time of my fieldwork. It meant, literally and metaphorically, the actions taken by the State towards people who its representatives felt were not supportive of their projects. To have one's water and light 'cut' meant to lose the connection to means of sustenance including state employment, places in schools, public services and more. Importantly, it would affect not only oneself, but one's entire extended family. Whilst Bruno was 'only' a scout leader, he had had some ability to be a little critical of the MPLA (as Ruben had been, at least in private), but now that he worked for 'them' as his official day job, he could not do it. Because of the principle of scout neutrality, Bruno explained, 'I don't wear my MPLA t-shirt to scouts, and I don't wear my scout $\mathrm{t}$-shirt to the MPLA, but the same heart beats underneath, and that heart is loyal to my scout irmãos [brothers, gender inclusive ${ }^{32}$ ] before the party.'

Here, the 'crevice' that is revealed is the profound awareness of individuals as to what is at stake, and the performances required of them. As elsewhere, the economically marginal in Angola had fewer options and almost no protection, and working with government was one of the few ways to improve their social and financial prospects. Like many such youth, Bruno had to consider not only his own needs, but the needs of his family. Ultimately his 'ideals' were of lesser significance than his grandmother's, parents' and siblings' well-being. The decision caused him emotional distress, but he felt he had little true choice. Echoing the observations of scholarly

32 I do not use the word 'sibling' here as I don't want to lose the loyal connotations of the word 'brother', which were an important part of this expression. 
literature ${ }^{33}$ Bruno's life required a performativity captured in a 'loyal $t$-shirt' that would be visible to the MPLA. At the same time, he hoped with painful sincerity that his friends and his scout 'brothers' would discerningly 'read his heart' and know a truth that could not be publicly stated.

\section{Third crevice: Hipólito's sacrifice}

The 'third crevice' is one of sadness, of grief that opened into a space of possibility for Angola going forward, of death, new symbols, and the after-life of instant action and reaction. On 22 of March 2014, a flash flood swept down the usually dry bed of a river not far from Benguela. The warning system that was supposed to be in place did not work and a group of children who were playing between the two banks were in danger of being washed away. Nearby, members of Scouts Troop \#44 were out on a hike. Taking stock of the situation, they rushed to help. Though they saved the children's lives, five scouts drowned, including their Chefe, a young man named Hipólito Candundo Pinto. ${ }^{34}$

The funeral was held in the Church of Nazareth in Benguela and attended by scouts from across the country. Black ribbons were passed around and carefully attached to each scout's uniform. The five coffins were laid out in the church, draped with both the Angolan flag and that of scouting. Chefe Ruben - described above helped to officiate the ceremony, which was attended by dignitaries from both local and national government as well as from scouts from across the country. In the many speeches that were given, reference was made again and again how Chefe Hipólito, in particular, had lead by example in a way that demonstrated the kinds of moral choices - and sacrifice - that were appropriate in the 'new' Angola.

Standing next to the coffins, Ruben's grief was etched starkly onto his face. For hours he guided mourners as they paid their last respects to Chefe Hipólito, who was 29 at the time of his death, and also to Manuel Segunda Chileme (aged 18), Sambo Victorino Fortunato (17), Joel dos Anjos Fernandes Borges (16), and Domingas Cassuma (11). The latter, the youngest and the only girl, was the sole daughter of a mother who clutched at her chest and keened throughout the ceremony. The keening rose and was joined by many others during a procession to the cemetery and the slow lowering of each coffin into the grave to the sound of hundreds of scouts singing a Portuguese language rendition of the British military bugle call, the 'Last Post.'

Continuing with El-Malik's tool of the crevice moment, the funeral for the young scouts was very powerful. It unified men and women and children around the country - and by extension, their families and church congregations - in reflecting on a moment of sacrifice for the good of other people. All the young children who had

J. Schubert, '2002, Year Zero: History as Anti-Politics in the "New Angola", Journal of Southern African Studies 41, 42015 https:// doi.org/10.1080/03057070.2015.1055548; G. Williams, 'Nationalisms, Nations and States: Concluding Reflections' in E. MorierGenoud (ed), Sure Road? Nationalisms in Angola, Guinea-Bissau and Mozambique (London: Brill.; Birmingham 2012), 197-293.; Péclard 2012.

In this case, I use his real name as the incident is easily identifiable through an internet search. 
been playing in the river were ultimately saved and again and again we heard about help reaching Chefe Hipólito as he lay on the bank of the river next to a plucked-out child, but how help came just too late to save him, and he had ascended to heaven on the basis of his good action. The deaths of the scouts allowed a rare moment of intergenerational connection where those who had served in the armed forces of Angola during the war could see within young Angola an example of the sacrifice that they had routinely had to make in a previous era. As Chefe Ruben grieved for his friend, Ruben's father remembered his own fallen comrades and, for the first time, Ruben said afterwards, there was a deeper understanding between them.

\section{The new (wo)men of Angola and soldiers for peace}

Ruben's choice, Bruno's compromise and Hipólito's sacrifice all reveal different dimensions of everyday life in a country which, for arguably the first time in centuries, found itself neither at war nor under foreign rule. Though hardly the first country in history to experience massive generational differences, Angolans had to contend not only with the changes of late capitalism in a petro-state economy, ${ }^{35}$ but also with the complexities of veterans whose lives had been largely shaped by civil war, now raising children in an era of peace. ${ }^{36}$

With this in mind, it is unsurprising that the scouts have proven both durable and successful in Angola's post-war landscape. The military structure of the organisation, with its hierarchy, uniform, duty and ideology, appeal to those older Angolans who feel that their time in the war served them well and helped them to grow, painful as it was for many. By the same token, the scout's positioning within church structures places it within a framework of civic action that has long existed and that has helped to address the human needs of many who the State, in its various precolonial, colonial and postcolonial formations, may have passed by. Self-sacrifice for the sake of small children is an extreme manifestation of that 'help' (more frequent were blood drives and house-painting and reading the bible with the elderly or sick) but the impetus remained the same: to learn through giving and to serve the community in whatever way was most needed, in accordance with both the church and Victorian England's notions of good behaviour and, interestingly, in a framework of the 'new man' which merits attention here.

Most scout meetings - like most public gatherings - included singing the National Anthem of Angola together, in which the heroes of the Angolan revolution are praised, and the 'sons ${ }^{37}$ who died for independence are 'saluted' before a commitment is made to 'build with work the new man. ${ }^{38}$ The caminheiros, in particular,

K. Reed, Crude Existence: Environment and the Politics of Oil in Northern Angola (Berkeley: University of California Press, 2009); J. Ovádia, 'The Reinvention of Elite Accumulation in the Angolan Oil Sector: Emergent Capitalism in a Rentier Economy', Cadernos de Estudos Africanos, 2013, 197-293; T. Hodges, Angola: Anatomy of an Oil State (Oxford: James Currey, 2010).

36 S. Makana, 'Motherhood as Activism in the Angolan People's War, 1961-1975', Meridians: Feminism, Race, Transnationalism, 15, 2, 2017, 353-81.

37 In theory, if not always in practice, this also includes the daughter of Angola (Makana 2017).

38 Angola, Assembléia Nacional. Angola: Constitução de Republico Luanda, 2011. 
hold up the figure of the 'new man' to be one to which they should aspire. It features centrally both in the literature they study before committing to the scout movement and in the way that Chefe Hipólito's death was later interpreted. It captured the transformation that the younger generation felt was necessary for the country and is an example of what was first written out of socialist principles meeting the Catholic interpretation of Christ and then being reconfigured through scouting into a $21^{\text {st }}$ century model of aspiration. ${ }^{39}$

This symbolic reconfiguring was one that happened at many dimensions through the scout movement. It had enough continuity with military structures that had gone before to be legible to both the MPLA and Angola's body of parents, but it also allowed young people to plug into an international network. This network was fun, well-dressed and globally relevant, and it created community, shared practice, friendship and activity that expanded the horizons of those who signed up. The interpretation of scouting as 'soldiers for peace' is not unique to Angola ${ }^{40}$ and 'bridged' a generational divide between those who had spent a good portion of their lives in the military and those who were now growing up in a country at peace. Though Lord Robert Baden-Powell's dictates in terms of dress were much critiqued (woollen socks in 40 degrees Celsius heat!) the structured curriculum, hierarchy and sense of duty appealed to many people of different ages and perspectives.

In the same vein, in the context of the revus and a gradually increasing space for alternative futures to be imagined (which manifest in the resignation of José Eduardo dos Santos in 2017), the identity of scouts as a 'mafia for peace' was also appealing. The idea of a 'mafia' spoke to those who were disillusioned with the political system, but nonetheless understood how it operated, and knew they had to work within it for the good of themselves, their families and their communities. The scouts therefore provided a space of multiple identities and negotiated dialogue, which took place in community halls, churches, schools and whilst out hiking. It was both highly localised and highly globalised in its symbols, practices and ways of being, and in the process it gave Angolans an identity that many felt truly proud of.

Scouting pulled open, expanded and chipped away at the accepted norms of discourse when it came to both politics and aspiration. Even though ultimately Ruben did not allow a conversation about Savimbi to take place in public, the seeds had emerged of a discourse that could blossom in private. Bruno's justifications of why he joined the MPLA meant that it was a decision that was no longer indicative of the only logical action available, and even Hipólitos death opened space for public reflection on what was really worth sacrificing one's life for: no longer the country, perhaps - instead, small children. In this way, scouting was less 'captured' by the MPLA's dominant discourses as strategically playing along. For those who were savvy, it was a place to be trained not only in what was, but what could be.

39 F. Arenas, Lusophone Africa: Beyond Independence (Minneapolis: University of Minnesota Press, 2011).

40 Parsons, 2004; S. Allison, 'Boy Scouts in a War Zone', Mail and Guardian, 3 January , 2019. 


\section{Conclusion: bridging the crevice}

In this paper, I have argued that the Angolan scouts play an important role in a country at peace. Drawing on Sheira El-Malik's notion of 'crevice moments' I have illustrated how scouting allowed spaces for Angola's social and political realities to be tested, and sometimes reconfigured, and how it provides a different entry point to Angolan nationalism(s) than that which has thus far been reflected in scholarly literature Though no clã was then named Savimbi, a debate did take place. Bruno remains with the MPLA, but it was not an automatic given. Hipólito's death did not change the desperate weakness of the emergency response system on the Cavaco river, but the children he rescued did survive. Participation in the dialogue and action around each event expanded the horizons of young Angolans trying to come of age at a moment where few models exist for citizenship in a country at peace. ${ }^{41}$ However, scouting as a movement offers one that has proven durable and replicable in extremely different social and political contexts, ${ }^{42}$ and young people in Angola - as elsewhere - are increasingly connected to and conscious of alternative realities that can effectively be video-streamed and sometimes manifested in actions.

Shortly after Hipólito's funeral, Ana-Flora, Gabriella, Ruben and Bruno gathered with around 200 other scouts on the beach of the Restinga, the long tip of Lobito that stretches into the Atlantic Ocean. They lit a massive fire and, under a pink sunset and long into the dark, reflected on what Hipólito's death had meant to each of them, and how to move forward with his sacrifice in their hearts'. They sang a hymn that does not feature in any international scout manual, but that encapsulates the need for both structure and friendship in the process of building a country. It also captures the need for a 'path to follow' - a touching reminder that 'new (wo)men' do not happen in a vacuum. Rather, religion, socialism, politics and youth identity all came together in Angolan scouting in a way that offers stability, structure and reimagination on rapidly shifting sands.

If you want to be better / but not greater / stretch out your hands like the divine Chefe / Come with me/ Come with me / Sing, Sing with me / There's a path to follow / You have in Scouts accompaniment, friendship, brotherhood / There's an obstacle to overcome / Our guide is Baden-Powell / and because of this we can do it! / Always prepared to sing / With desire to serve Angola my country / with me, you can tell all. 